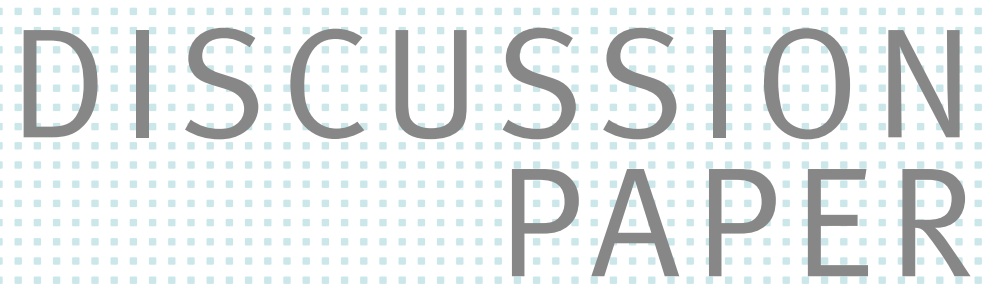

// JENS HORBACH AND CHRISTIAN RAMMER

Labor Shortage and Innovation 


\title{
Labor Shortage and Innovation
}

\author{
Jens Horbach ${ }^{1}$ and Christian Rammer ${ }^{2}$
}

February 2020

\begin{abstract}
Skilled labor is a key input to the innovation process. A shortage in supply of skilled labor may hence impede innovation activities, resulting in lower productivity gains. While governments are concerned about these likely negative impacts, there is only limited empirical evidence whether and to what extent labor shortage affects innovation activities. The paper addresses this question using panel data from three waves (2017 to 2019) of the German innovation survey. We measure labor shortage by job openings that could not be filled at all, not with the required skills or only with significant delay, distinguishing different skill levels. We analyze whether labor shortage resulted in stopping or abandoning of innovation projects. Endogeneity issues are tackled by instrumental variable estimation techniques. Our results show that innovative firms are more likely to be subject to skill shortage, whereas skill shortage induces the cancelation of innovation projects. Effects are stronger for labor shortage related to professional occupations and less for academic qualifications.
\end{abstract}

JEL-Classification: J23, J24, O31, C26

Key words: Community Innovation Survey, labor shortage, innovation, probit instrumental variable estimation

\footnotetext{
${ }^{1}$ University of Applied Sciences Augsburg, Germany, jens.horbach@hs-augsburg.de

${ }^{2}$ Centre for European Economic Research (ZEW), Mannheim, Germany, rammer@zew.de
} 


\section{Introduction}

By the end of the 2010s, labor shortage has become a key policy issue in Germany. On the one hand, a long-lasting upswing of the German economy raised labor demand. On the other hand, demographic change widens the gap between the number of retiring workers and young workers newly entering the labor market. As a result, the German unemployment rate fell to $3.4 \%$ in 2018, the second lowest value in the EU (Eurostat 2019). For skilled labor, unemployment rates are less than half this value (Röttger et al. 2019), causing increasing problems for firms that want to fill job openings for high-qualified occupations.

Surprisingly, there are only few empirical analyses on the consequences of labor shortage for the economy. In that context, a crucial question is whether a lack of skilled labor hampers the innovativeness of firms. On the one hand, innovative firms may have a disproportionately high skilled labor shortage compared to other firms because of their higher need of high qualified and specialized staff. Skilled labor shortage might hence hamper investment and innovation activities in these firms and constitute a severe obstacle for productivity and growth opportunities. On the other hand, innovative firms may be able and willing to pay higher wages for skilled labor than non-innovative firms and absorb most of the scarce supply, causing higher troubles for non-innovative firms.

Our empirical analysis firstly addresses the question whether innovative firms are disproportionally affected by labor shortage. In a second step, we analyze whether labor shortage hampers innovation output and if yes, which qualification levels are most relevant. Likely negative consequences of labor shortage on innovation are measured by project cancelation, i.e. whether firms had to stop or abandon some of their innovation activities.

For our analysis, we use a unique data basis of three panel waves (2017 to 2019) of the German part of the Community Innovation Survey (CIS). The survey wave 2018 contained a special module on labor shortage that can be combined with detailed data on firms' innovation activities.

The econometric analysis is challenging as there are potential endogeneity problems. On the one hand, more innovation activities and more ambitious innovation may trigger shortage in skilled labor. On the other, (expected) labor shortage may lead firms to reduce the extent and scope of their innovation activities or refrain from any such activities. Analyzing the abandon- 
ment of innovation activities faces endogeneity issues, too, because the discontinuation of innovation projects due to a lack of skilled personnel might also mitigate labor shortage. We apply instrumental variable techniques to address these endogeneity issues.

The paper is organized as follows. Section 2 discusses the definition and determinants of labor shortage and their relationship to innovative behavior of firms from a theoretical perspective. Section 3 presents the empirical strategy, the data base and the indicators used for measuring innovation and labor shortage. This section also contains descriptive statistics on innovation and labor shortage. The econometric results of our instrumental variable estimations are presented in Section 4 whereas Section 5 concludes and discusses policy recommendations.

\section{Theoretical aspects of the relationship between (skilled) labor shortage and innovativeness}

Following the Knowledge Production Function (KPF) approach (see e.g. Slavtchev 2005, Wagner 2006, Czarnitzki et al. 2009) the generation of new knowledge in a firm $i\left(\triangle K P_{i}\right)$ does not only depend on $\mathrm{R} \& \mathrm{D}$ expenditure $\left(R \& D_{i}\right)$ but especially on the availability of skilled labor (human capital, $H C_{i}$ ). Besides these important inputs, the information flows within the firm $\left(I F_{i i}\right)$ and with other firms $j(I F i j)$, e.g. via regional spill-over effects, are crucial for firms' innovation performance. Furthermore, factors such as firm size, industry, international activities or the competition situation $\left(X_{i}\right)$ are important for the production of new knowledge.

$\Delta K P_{i}=f\left(R \& D_{i}, H C_{i}, I F_{i i}, I F_{i j}, X_{i}\right)$

Piva and Vivarelli (2009:837) argue that "labour skills are crucial in enhancing innovation in terms of individual creativity, organizational change and acquisition of external knowledge. (...) skilled employees who feel confident in performing a range of proactive tasks requiring autonomous initiative are surely more likely to be successful in exploring and/or exploiting innovative ideas”. Following the management literature (see e.g. Svetlik and Stavrou-Costea 2007 or Song et al. 2003), skilled workers are more able to deal with complexity and they are more creative, hence enhancing innovation processes. Consequently, innovation activities will lead to higher innovation success if a firm possesses enough human capital that is able to manage complex organizational processes, to efficiently transmit tacit knowledge and to generate and implement new ideas. A shortage of skilled labor may thus act as a severe barrier for innovation success. On the other side, Acemoglu (2010) shows that this is only true if the new 
technology is not labor saving because labor saving innovations might be even spurred by labor shortage.

\section{Determinants of labor shortage}

A universally accepted definition of (skilled) labor shortage does not exist (OECD 2003). From a strict neoclassical point of view, there would be no labor shortage because the price mechanism would always induce an equilibrium of demand and supply of labor. Labor shortage hence reflects a too slow adjustment of prices (wages) because of high adjustment costs. In fact, it is difficult for a firm to pay higher wages to new employees as this would signify to raise the wages of the personnel already employed (Arrow and Capron 1959). In a study for Australia, Junankar (2009:3) confirms the slow adjustment of wages as a cause for labor shortage. He states that "standard neoclassical economics predicts that if there is a skills shortage, the labour market would respond with large increases in wage rates. Our results, however, show that real wages were growing at a relatively slow rate (compared to productivity growth) and even in Western Australia and Queensland the wage rates of skilled occupations were growing very slowly."

Shah and Burke (2003:v) define labor shortage as follows: “A shortage occurs when the demand for workers for a particular occupation is greater than the supply of workers who are qualified, available and willing to work under existing market conditions.” ... "Over time, the market might adjust in a number of ways, including price and/or quantity adjustment, and the imbalance clears.”

There are further determinants of labor shortage besides wage adjustment problems and a higher labor demand (see Table 1). In the long run, labor shortage problems may also result from demographic change if there will be no compensation by increased immigration or a higher willingness to participate in the labor market. This is particularly true for Germany. Following a study of Fuchs and Söhnlein (2013), without considering migration effects the active population (between the age of 15 and 66) would shrink from 55 million in 2010 to 30 million in 2060. Including substantial migration, an optimistic scenario estimates an active population of 45 millions in 2060.

There is an extensive literature (see e.g. Berlingieri and Erdsiek 2012) analyzing further supply side factors such as personal characteristics of job searchers (e.g. over-qualification, family or partner related reasons) that may lead to a mismatch of labor supply and demand. 
Concerning labor demand, the innovativeness of a firm may be highly correlated to (skilled) labor shortage problems because innovative firms may need more qualified personnel compared to other firms. High-qualified employees are much more scarce compared to unskilled workers. In 2018, the German unemployment rate of persons with a university degree was only $2.0 \%$ (based on the German government's definition of unemployment) whereas the respective figure for no-trained persons was $17.4 \%$ (Röttger et al. 2019). Furthermore, especially in new and rapidly emerging innovation fields such as information technologies, demand for new qualification profiles may be particularly high and lead to scarcity. There are also mere capacity effects because innovation activities are accompanied by additional investments and innovative firms are characterized by a higher demand and competitiveness.

Table 1: Determinants of shortage of (skilled) labor

\begin{tabular}{|c|c|}
\hline Labor supply & Labor demand \\
\hline 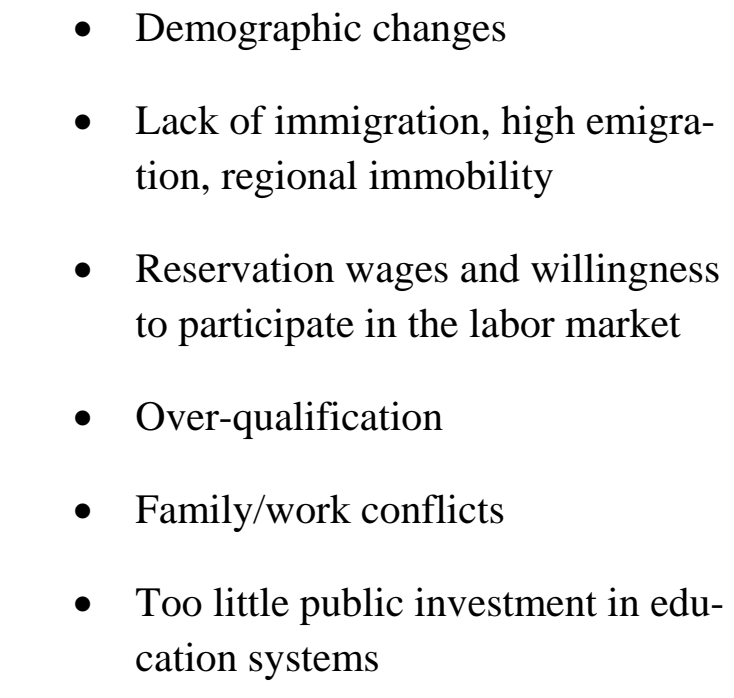 & $\begin{array}{l}\text { - Innovation activities requiring new } \\
\text { qualified personnel } \\
\text { - High product demand (business cy- } \\
\text { cle) } \\
\text { - High recruiting costs } \\
\text { - } \quad \text { Qualification-related mismatch be- } \\
\text { cause of structural change } \\
\text { - } \quad \begin{array}{l}\text { Reluctance to approach new groups } \\
\text { of workers: (e.g. inexperienced grad- }\end{array} \\
\text { uates, elder personnel, migrants) }\end{array}$ \\
\hline
\end{tabular}

Source: Adapted from Horbach (2014), Kettner (2012).

Measuring labor shortage is a challenging task (see also Shah and Burke 2003). Vacancy rates in combination with unemployment would be a useful indicator but reliable statistics of job vacancies are difficult to collect. The German Institute for Employment Research uses a survey to capture the number of vacancies in the German economy (see Müller et al. 2012, Brücker et al. 2013). Nevertheless, the measurement of "normality” remains arbitrary: How many applicants per job offer already constitute a labor shortage problem? Most empirical analyses use survey results capturing the individual perception of firms' labor and skill shortages. A caveat of this approach is that the questioned firms might show a tendency to exaggerate labor shortage 
in their answers (see also Barnow et al. 2013 and Green et al. 1998). In addition to this argument, Arrow and Capron (1959) point to the fact that if firm representatives are asked about labor shortage they talk about "unfilled vacancies with salaries equal to those of engineers and scientists now employed by the firm and performing equivalent services.” The self-perception of labor shortage is thus not independent from existing working conditions and wages of the questioned firms.

\section{Literature overview on the relationship between innovation and labor shortage}

There is an extensive literature on the general impacts of innovation on employment (see Barbieri et al. 2019 for a recent overview), but empirical analyses on the relationship between innovation and (skilled) labor shortage are quite rare. One exception is the study of Cedefop (2015) based on data of the Eurobarometer survey no. 196 conducted in 2006. The authors show that "genuine skill deficits have a negative impact on the ability of smaller-sized firms to introduce innovative practices” (Cedefop 2015:80) using a linear probability model. Their analysis is restricted to SMEs. Furthermore, the authors do not account for the possible endogeneity of innovative practices which might increase skilled labor shortage in a firm. Based on data for Northern Ireland, Bennett and McGuinness (2009) analyze the impact of skill shortages on the productivity performance of high-tech firms. The authors find that "both hard-to-fill and unfilled vacancies had reduced output per worker levels by between 65 and $75 \%$ in affected firms" (Bennett and McGuinness 2009:727). Tang and Wang (2005) confirm the negative impact of skill shortages on performance of small and medium-sized firms for a sample of Canadian manufacturing firms in 1999. Using quantile regressions based on the UK Community Innovation Survey (CIS) panel data from 2002-2010, Coad et al. (2016) find out that the lack of qualified personnel is an important innovation barrier for high productivity firms. Haskel and Martin (2006) detect a gap between supply and demand of skills for the UK manufacturing industry whereas unskilled shortages seem to be rare. The authors show that the growth of skill shortages in the UK during the 1980s reduced productivity growth by approximately $0.4 \%$ per year. For the US, Cappelli (2015:251) is quite skeptic concerning the role of skills shortage: "Very little evidence is consistent with the complaints about a skills shortage, and a wide range of evidence suggests the complaints are not warranted.“

Freel (2005:123) analyzes the relationship of different skill levels and innovation activities. His study accentuates the relevance of “intermediate 'technical' skills, rather than higher level ‘technology’ skills” for the innovation performance of firms. McGuinness et al. (2017) use data 
from the European Skills and Jobs Survey to analyze the incidence of different types of skill mismatch across the EU. Toner (2011) provides an overview on analyses of the general relationship between skills and innovation. He concludes that differences in the quantity and quality of skills are crucial for innovation activities. Baird et al. (2019) analyze the expected excess demand for anesthesiologists in 2013 with a focus on different model specifications.

Healy et al. (2015) discuss different strategies of Australian SMEs to overcome skill shortages based on the Australian Business Longitudinal Database. The SMEs report strategies such as a better utilization of their existing manpower by increasing the working hours or even radical options such as reducing output.

Cui et al. (2018) analyze the determinants of labor shortage in China on a macroeconomic level. The authors find that especially structural demographic changes and regional economic growth disparities lead to labor shortage problems.

Based on our theoretical considerations and the literature review, we formulate the following hypotheses:

H1 Innovative firms are stronger affected by labor shortage because of their higher need and skill requirements.

H2 A high product demand and a good profit situation is positively correlated to labor shortage.

H3 A higher regional labor supply leads to less labor shortage in firms.

H4 A lack of skilled labor restricts innovation activities.

\section{Empirical strategy and data}

Our empirical setup for testing the hypotheses consists of two interrelated models (see Figure 1). In a first step, we analyze the determinants of labor shortage with a special focus on the role of innovation activities (Model 1). We use various dependent variables to capture differences in the severity of labor shortage and differences in the required skill levels. The key variable of interest in the first model is innovation activities. While we expect that a higher level of past and current innovation activities will lead to more severe labor shortage, expected labor short- 
age may also negatively affect innovation activities. For example, firms may refrain from starting certain innovation projects or downscale projects if they expect not to find the staff they would need to conduct these projects. Therefore, the innovation variable in the first model may be endogenous.

In a second step, we analyze the relevance of labor shortage in period $t$ for abandoning innovation activities in the same period or in the future period $t+1$ (Model 2). As abandoning of innovation activities strongly depends on the breadth on innovation activities (i.e. firms with many or diverse activities are more likely to stop at least one of these activities, see Klingebiel and Rammer 2014), we control for innovation breadth. Once again, there are endogeneity problems both with the labor shortage and the innovation breadth variables. Innovation failure can reduce labor shortage, particularly if abandoning of innovation activities is not a sudden decision taken but the end of a longer process of downsizing the activity. In such a case, downsizing may have led to lower labor demand, reducing the severity of labor shortage. In a similar vein, planned abandoning of innovation activities can affect the breadth of innovation activities undertaken by a firm.

\section{Figure 1: Estimation strategy}

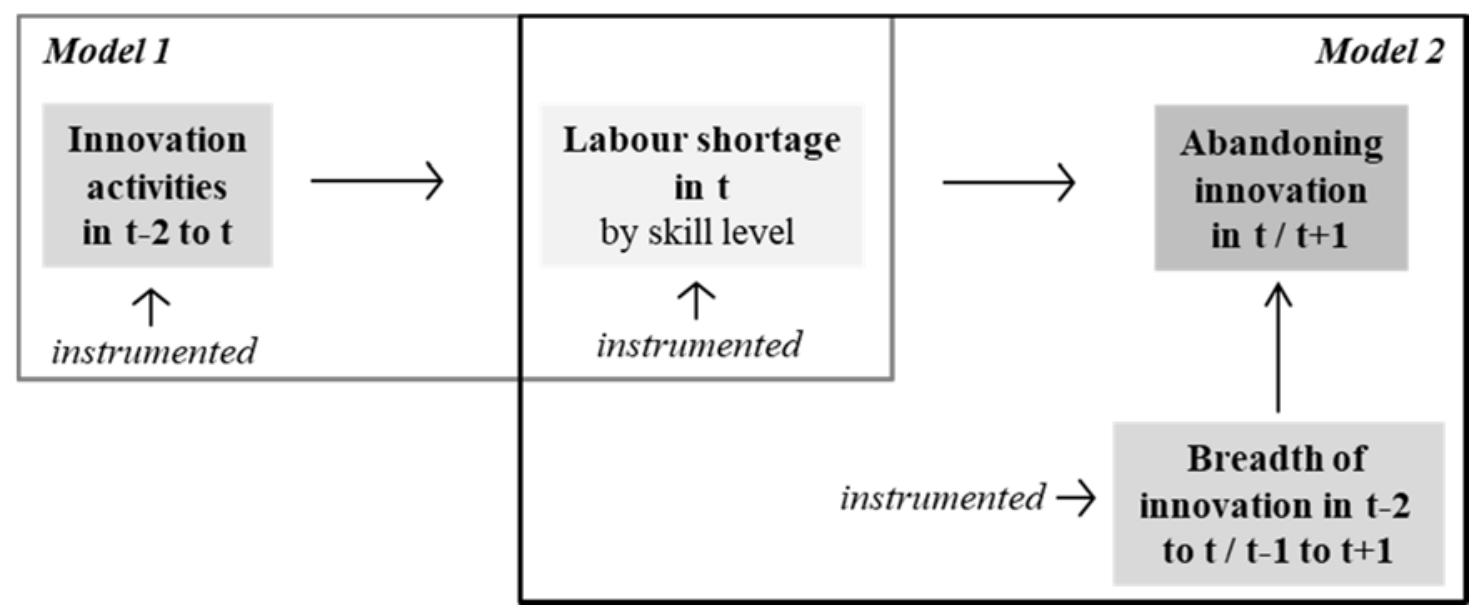

To address likely endogeneity issues, we estimate instrumental variable (IV) regressions of $y_{i}$ on exogenous covariates $\mathbf{x}_{i}$ and $c(c=1,2)$ endogenous variables. The vector $\mathbf{z}_{\mathrm{c} i}$ contains the variables from $\mathbf{x}_{i}$ and other covariates affecting $w_{c i}$ but that are not correlated to $y_{i}$.

$y_{i}=\mathbf{x}_{\mathbf{i}} \boldsymbol{\beta}+w_{c i} \widehat{\beta}_{\mathrm{c}}+\varepsilon_{i}$

$w_{c i}=\mathbf{z}_{\mathrm{ci}} \gamma_{\mathrm{c}}+\boldsymbol{\varepsilon}_{c i}$ 


\section{Data}

The empirical analysis is based on firm-level panel data from three waves (2017, 2018 and 2019) of the German part of the Community Innovation Survey (CIS). The 2018 wave contained a special module on labor shortage for the reference year 2017 including measures on shortage for different qualification levels. While each survey wave collects data of around 8,000 different firms, combining consecutive survey waves and considering only firms with full information on all model variables reduces the sample size to 2,816 to 3,519 (depending on the model variant).

The German CIS is based on the same methodological standards of all CIS which have been developed and are supervised by the Statistical Office of the European Commission (Eurostat). Differently to the CIS, which is a biennial survey, the German survey is conducted annually and employs a panel approach which allows to track firms' innovation behavior over time. The survey is based on a stratified random sample, using eight size classes, 56 sectors (both manufacturing and services) and two regions as stratification criteria. The survey is voluntary, and the response rate is between 25 and 30\%. A comprehensive non-response survey is used to correct for a potential response bias. The survey form, which is available as paper and online versions, is usually completed by CEOs or innovation managers. For more information on the German CIS, see Peters and Rammer (2013) and Behrens et al. (2017).

The module on labor shortage in the 2018 survey collected data on whether firms had job openings during 2017 and how they were able to fill the vacancies, offering four options: filled as planned, filled with delay, filled with other than the desired personnel, and filled not at all. In addition, the survey asked on the qualification levels associated with these vacancies, distinguishing nine qualification levels. The exact wording and design of the question is shown in the Appendix. The questions follow a similar approach to that used by the Institute for Employment Research of the German Federal Labor Agency when collecting data on the number of vacancies in the German economy (see Müller et al. 2012, Brücker et al. 2013).

We construct several measures of labor shortage in the year 2017. Laborshortbroad is a broad indicator for labor shortage including vacancies that could either not be filled or filled only with delay or not with the desired personnel. The narrow definition of labor shortage ( $L a$ borshortnarrow) only considers vacancies that could not be filled at all. AcademicLS, VocationalLS and UnskilledLS are variables capturing labor shortage in academic qualifications, vocational qualifications and unskilled occupations, respectively. SkilledLS summarizes labor 
shortage in academic and vocational educations. A further aspect of labor shortage is the variety of qualifications. Qualcount captures the number of different required qualifications for vacancies (ranging from 1 to 9). This indicator thus describes the broadness of labor shortage problems in a firm. In addition, we use a variable Pathdep that indicates the lack of suitable qualified staff in the previous period 2014-2016, thus capturing the path dependence of labor shortage.

The descriptive results for the labor shortage variables (Table 2) show that labor shortage problems seem to be more important for innovation active firms compared to all firms. $43.8 \%$ of innovation active firms report some type of labor shortage, compared to $39.6 \%$ for all firms. Labor shortage in innovation active firms seems to be especially important for vocational qualifications.

Table 2: Labor shortage in German firms 2017

\begin{tabular}{|l|c|c|}
\hline Labor shortage indicators & \% of all firms & $\begin{array}{c}\text { \% of all innova- } \\
\text { tion active firms }\end{array}$ \\
\hline Laborshortbroad & 39.6 & 43.8 \\
\hline Laborshortnarrow & 20.1 & 19.1 \\
\hline AcademicLS & 13.3 & 20.0 \\
\hline VocationalLS & 28.6 & 33.7 \\
\hline UnskilledLS & 21.4 & 21.6 \\
\hline
\end{tabular}

Source: German Innovation Survey 2018, weighted data.

\section{Definition and measurement of other model variables}

Innovation activities are measured through a dummy variable getting the value one if the firm introduced product or process innovations during 2015 and 2017 (Innovation). Furthermore, the variable Innobreadth captures the number of different innovation activities (running from 1 to 17) by counting the different types of product and process innovations a firm has introduced during a three-year period, and the number of different innovation activities. Innovation failure describes the abandonment of innovation activities in the current period (Innovationfail2017) and in the following period (Innovationfail2018) respectively. ${ }^{1}$ Furthermore, the innovative capacity of a firm is described by the share of employees with a university degree in 2016 (Shareacad).

\footnotetext{
${ }^{1}$ In the questionnaire, firms are asked whether they have abandoned innovation activities during a three-year reference period. Firm-level panel data of the responses suggest that firms mainly refer to the last year of this period when reporting on innovation failure, as one frequently observes that firms reported no innovation failure in a t-1 survey, followed by reporting innovation failure in the next survey (in t), and again not innovation failure in
} 
Furthermore, we include the following control variables: Agefirm denotes the age of the firm. The competition situation is characterized by Compabroad describing the competition by foreign firms whereas Newcomp describes the threat to market positions because of new entrants. Furthermore, Substitutability describes the easiness to substitute the own products by those of competitors. Shortlifecycle gets the value one if the firm operates in an environment where products or services are rapidly obsolete. The effect if price changes induce a loss of customers is captured by Pricecomp. The demand for a firm's products that may result in higher demand for labor in 2017 is indicated by turnover growth from 2016 to 2017 (Demand). A further indicator for the economic performance of the firm is Empdynamic denoting the annual growth of employment from 2010 to 2017. Credrating denotes the financial standing of the firm, EastGermany gets the value one if the firm is located in the eastern part of Germany and the Size of the firm is captured by the number of employees. Furthermore, sector dummies are included.

Regional framework conditions and spill-over effects are represented by the following variables at the NUT3 level (German districts) related to the reference year 2016: Dedomainpc denotes the number of de-domains per capita indicating the digitalization level of a region. The population density (Popdensity) indicates agglomeration effects. The regional economic performance is captured by the GDP per employee (GDPemp) and the unemployment rate (Unemprate). This data is taken from the regional database of the Federal Statistical Office in Germany (Statistisches Bundesamt 2019).

For instrumenting the innovation and labor shortage variables, we tested a series of potential instruments. Finally, the following variables turned out to be valid instruments. For Innovation and Innobreadth, we use the regional digitalization level (Dedomainpc) denoting regional spillover effects that support the innovation activities of the firm, the intensity of the competition from abroad (Compabroad) forcing firms to be more competitive by innovation activities and the share of academic staff (Shareacad) as a human capital indicator. The labor shortage variables are instrumented by the regional GDP per employee denoting the regional economic situation. A high GDP per employee (GDPemp) is expected to be positively correlated to labor shortage because in rich regions the demand for skilled labor is higher. Furthermore, the variable Shortlifecycle is used as instrument for skilled labor shortage because in branches where products or services are rapidly obsolete more qualified staff is needed to realize the design of new or the modification of existing products. Unskilled labor shortage is instrumented by the

the subsequent survey $\mathrm{t}+1$. Such a response pattern is obviously inconsistent with a three-year reference period. We therefore assume that innovation failure predominantly refers to the reference year of the survey. 
variable Substitutability because unskilled labor shortage is more likely in branches where standardized and easily substitutable products dominate.

The definition of all model variables and descriptive statistics are shown in Table A1 in the Appendix.

\section{Econometric results}

Models 1 and 2 are estimated using IV probit regressions, except for the variable Qualcount (number of different required qualifications for vacancies) for which a Poisson regression model has been estimated. The results are reported in Table 3 .

Table 3: Determinants of labor shortage in German firms

\begin{tabular}{|c|c|c|c|}
\hline \multirow{2}{*}{ Correlates } & \multicolumn{3}{|c|}{ Dependent variables } \\
\hline & Laborshortbroad & Laborshortnarrow & Qualcount \\
\hline Agefirm & $-0.005(-1.29)$ & $-0.005(-1.73)^{+}$ & $-0.01(-1.37)$ \\
\hline Demand & $0.11(2.54)^{* *}$ & $0.00(1.45)$ & $0.32(2.75)^{* *}$ \\
\hline Empdynamic & $0.40(2.95)^{* *}$ & $0.004(0.04)$ & $0.54(1.04)$ \\
\hline EastGermany & $0.02(1.99)^{*}$ & $0.03(2.43)^{* *}$ & $0.03(0.39)$ \\
\hline Innobreadth & - & - & $0.16(2.60)^{* *}$ \\
\hline Innovation & $0.45(7.73)^{* *}$ & $0.27(3.23)^{* *}$ & - \\
\hline Newcomp & $-0.03(-1.55)$ & $-0.04(-2.23)^{*}$ & $-0.08(-1.65)^{+}$ \\
\hline Pathdep & $0.15(4.28)^{* *}$ & $0.10(3.94)^{* *}$ & $0.25(4.13)^{* *}$ \\
\hline Popdensity & $0.01(1.79)^{+}$ & $0.01(1.66)^{+}$ & $0.03(1.50)$ \\
\hline Pricecomp & $0.06(2.80)^{* *}$ & $0.04(2.29)^{*}$ & $0.13(2.35)^{*}$ \\
\hline Credrating & $0.08(1.98)^{*}$ & $0.05(1.51)$ & $0.24(2.48)^{* *}$ \\
\hline Shareacad & $-0.14(-5.81)^{* *}$ & $-0.05(-2.81)^{* *}$ & $-0.53(-2.83)^{* *}$ \\
\hline Size & $0.09(0.16)$ & $-0.03(-0.03)$ & $0.002(0.71)$ \\
\hline Substitutability & $0.02(1.00)$ & $0.006(0.54)$ & $0.08(1.43)$ \\
\hline Unemprate & $-0.62(-1.19)$ & $-0.75(-1.88)^{+}$ & $-1.10(-1.05)$ \\
\hline \# observations & 2,816 & 2,816 & 2,816 \\
\hline Wald Chi ${ }^{2}$ & 446.5 & 144.9 & \\
\hline \multicolumn{4}{|c|}{$\begin{array}{l}\text { Probit model (Laborshortbroad and Laborshortnarrow) and poisson model (Qualcount) with endogenous co- } \\
\text { variate. The endogenous variables Innovation and Innobreadth are instrumented. Instruments for these varia- } \\
\text { bles: Compabroad, Dedomainpc. Robust and clustered standard errors. Instead of coefficients, average mar- } \\
\text { ginal effects are reported. Concerning dummy variables, the values report changes in probability for discrete } \\
\text { changes of dummy variables from } 0 \text { to } 1 \text {. Z-statistics are given in parentheses. +, *, and ** denote significance } \\
\text { at the } 10 \%, 5 \% \text {, and } 1 \% \text { levels, respectively. Sector dummies and constants are included but not reported. }\end{array}$} \\
\hline
\end{tabular}

Source: German Innovation Surveys 2017 and 2018.

The results show that innovative firms (innovation) are more likely to be characterized by skilled labor shortage supporting our hypothesis H1. Labor shortage also seems to be path- 
dependent (Pathdep) because firms with labor shortage in the past are more likely to be characterized by labor shortage in the future. Good performing firms characterized by a high $D e$ mand and a good profit situation (Credrating) are more likely to have labor shortage (supporting H2). In regions with a high unemployment rate (Unemprate) labor shortage in the narrow definition seems to be less important (H3) whereas a high population density (Popdensity) indicating agglomeration effects is positively (but only weakly significant) correlated to labor shortage.

Interestingly, firms showing a high share of academic staff (Shareacad) are less affected by labor shortage problems pointing to the fact that labor shortage in academic professions seems to be a less important problem.

The results are confirmed when the qualification broadness of the vacant positions in a firm is analyzed. A high broadness (Innobreadth) of innovation activities is correlated to a higher number of qualification levels measured by Qualcount. Firms with labor shortage in the past (Pathdep) also show a higher diversity of qualifications in their vacant positions.

The results for the innovation failure model (Tables 4 for 2017 and Table 5 for 2018) show that labor shortage (Laborshortbroad) induces innovation failure measured by the cancelation of innovation projects supporting H4. Analyzing different qualification levels, this result is only valid for skilled labor shortage whereas labor shortage of unskilled employees does not seem to hamper innovation projects. Interestingly, a further split between vocational training (production and information technologies) and academic skills leads to the result that especially the first acts as a significant barrier to innovations. 
Table 4: Innovation failure in 2017 and labor shortage in Germany

\begin{tabular}{|c|c|c|c|c|c|}
\hline \multirow[t]{2}{*}{ Correlates } & \multicolumn{5}{|c|}{ Dependent variable: Innovationfail2017 } \\
\hline & $\begin{array}{l}\text { Labor short- } \\
\text { age in gen- } \\
\text { eral }\end{array}$ & $\begin{array}{l}\text { Skilled la- } \\
\text { bor shortage }\end{array}$ & $\begin{array}{l}\text { Academic la- } \\
\text { bor shortage }\end{array}$ & $\begin{array}{l}\text { Vocational la- } \\
\text { bor shortage }\end{array}$ & $\begin{array}{l}\text { Unskilled la- } \\
\text { bor shortage }\end{array}$ \\
\hline \multicolumn{6}{|l|}{ Labor shortage } \\
\hline Laborshortbroad & $0.15(2.68)^{* *}$ & - & - & - & - \\
\hline SkilledLS & & $0.12(2.29)^{*}$ & & - & - \\
\hline AcademicLS & - & - & $0.06(1.39)$ & & - \\
\hline Vocationa & - & - & - & $0.14(1.95)^{*}$ & \\
\hline UnskilledLS & - & - & - & - & $0.10(0.88)$ \\
\hline \multicolumn{6}{|l|}{$\begin{array}{l}\text { Control varia- } \\
\text { bles }\end{array}$} \\
\hline Agefirm & $-0.00(0.17)$ & $-0.00(0.17)$ & $-0.00(-0.11)$ & $-0.00(0.22)$ & $0.00(0.01)$ \\
\hline EastC & $-0.01(-2.04)^{*}$ & $-0.01(-1.84)$ & $-0.02(-2.03)^{*}$ & $-0.02(-1.67)$ & $-0.02(-1.81)^{+}$ \\
\hline Empdynamic & $-0.03(-1.27)$ & $-0.04(-1.19)$ & $-0.04(-0.79)$ & $-0.04(-1.28)$ & $-0.04(-1.06)$ \\
\hline Innobreadth & $0.02(2.30)^{*}$ & $0.02(2.29)^{*}$ & $0.02(2.08)^{*}$ & $0.02(2.52)^{* *}$ & $0.02(2.87)^{* *}$ \\
\hline Credrating & $-0.02(-2.35)^{*}$ & $-0.02(-2.42)^{*}$ & $-0.02(-2.04)^{*}$ & $-0.02(-2.38)^{*}$ & $-0.01(-1.77)^{+}$ \\
\hline Size & $0.03(4.09)^{* *}$ & $0.03(4.16)^{* *}$ & $0.03(4.09)^{* *}$ & $0.03(4.03)^{* *}$ & $0.03(3.79)^{* *}$ \\
\hline \# observations & 3,519 & 3,519 & 3,519 & 3,519 & 3,515 \\
\hline Wald Chi ${ }^{2}$ & 221.1 & 193.3 & 167.3 & 212.5 & 195.9 \\
\hline \multicolumn{6}{|c|}{$\begin{array}{l}\text { Probit model with endogenous covariates. The endogenous variables Innobreadth, Laborshortbroad, } \\
\text { AcademicLS, SkilledLS, VocationaLS and UnskilledLS are instrumented. Instruments for Innobreadth: Dedo- } \\
\text { mainpc, Shareacad. Instruments for Laborshort, AcademicLS, SkilledLS, VocationalLS: Shortlifecycle, } \\
\text { GDPemp. Instrument for UnskilledLS: Substitutability. Robust and clustered standard errors. Instead of coeffi- } \\
\text { cients, average marginal effects are reported. Concerning dummy variables, the values report changes in proba- } \\
\text { bility for discrete changes of dummy variables from } 0 \text { to } 1 \text {. Z-statistics are given in parentheses. +, *, and ** } \\
\text { denote significance at the } 10 \%, 5 \% \text {, and } 1 \% \text { levels, respectively. Sector dummies and constants are included but } \\
\text { not reported. }\end{array}$} \\
\hline
\end{tabular}

Source: German Innovation Surveys 2017 and 2018.

Not surprisingly, innovative firms (innobreadth) are more likely for innovation failures. Furthermore, a bad profit (credrating) situation is correlated to more innovation failures.

A further analysis for innovation failures in 2018 (see Table 5) confirms the path-dependence of labor shortage in firms. Labor shortage in 2017 also hampers innovation activities in 2018. Once again, this result especially holds for vacancies requiring skilled qualification levels. 
Table 5: Innovation failure in 2018 and labor shortage in Germany

\begin{tabular}{|c|c|c|c|}
\hline \multirow[t]{2}{*}{ Correlates } & \multicolumn{3}{|c|}{ Dependent variable: Innovationfail20178 } \\
\hline & $\begin{array}{l}\text { Labor shortage } \\
\text { in general }\end{array}$ & $\begin{array}{l}\text { Skilled labor } \\
\text { shortage }\end{array}$ & $\begin{array}{c}\text { Unskilled labor } \\
\text { shortage }\end{array}$ \\
\hline \multicolumn{4}{|l|}{ Labor shortage } \\
\hline Laborshortbroad & $0.24(2.43)^{* *}$ & - & - \\
\hline SkilledLS & - & $0.18(2.43)^{* *}$ & - \\
\hline UnskilledLS & - & - & $0.08(0.91)$ \\
\hline \multicolumn{4}{|l|}{ Control variables } \\
\hline Agefirm & $0.00(0.84)$ & $0.00(0.77)$ & $0.00(0.38)$ \\
\hline EastGermany & $-0.03(-2.65)^{* *}$ & $-0.03(-2.54)^{* *}$ & $-0.03(-2.80)^{* *}$ \\
\hline Empdynamic & $-0.00(-0.61)$ & $0.05(-0.46)$ & $-0.04(-0.09)$ \\
\hline Innobreadth & $0.02(2.86)^{* *}$ & $0.02(2.91)^{* *}$ & $0.02(3.49)^{* *}$ \\
\hline Credrating & $-0.00(-1.32)$ & $-0.00(-1.11)$ & $-0.00(-0.42)$ \\
\hline Size & $0.02(2.19)^{*}$ & $0.02(2.65)^{* *}$ & $0.02(2.86)^{* *}$ \\
\hline \# observations & 3,169 & 3,168 & 3,169 \\
\hline Wald $\mathrm{Chi}^{2}$ & 301.6 & 250.1 & 213.4 \\
\hline \multicolumn{4}{|c|}{$\begin{array}{l}\text { Probit model with endogenous covariates. The endogenous variables Innobreadth, La- } \\
\text { borshortbroad, AcademicLS, SkilledLS and UnskilledLS are instrumented. Instruments for } \\
\text { Innobreadth: Dedomainpc, Shareacad. Instruments for Laborshort and UnskilledLS: Substi- } \\
\text { tutability18, GDPemp. Instruments for SkilledLS: Compabroad18, Substitutability } 18 \text {, } \\
\text { GDPemp. Robust and clustered standard errors. Instead of coefficients, average marginal ef- } \\
\text { fects are reported. Concerning dummy variables, the values report changes in probability for } \\
\text { discrete changes of dummy variables from } 0 \text { to } 1 \text {. Z-statistics are given in parentheses. +, *, } \\
\text { and ** denote significance at the } 10 \%, 5 \% \text {, and } 1 \% \text { levels, respectively. Sector dummies and } \\
\text { constants are included but not reported. }\end{array}$} \\
\hline
\end{tabular}

Source: German Innovation Surveys 2017 to 2019.

\section{Summary and policy implications}

The lack of skilled labor is highly present in the public discussion on obstacles to innovation, reflecting challenges from demographic change. But there are surprisingly few empirical analyses on this topic. The present paper tries to fill this gap using panel data of most recent waves of the German part of the Community Innovation Survey (CIS). Following the knowledge production function approach, the existence of (high) skilled labor force is crucial for the innovation success of firms. Thus, innovative firms will disproportionally need skilled staff so that they are particularly affected by a shortage of skilled labor. Our empirical analysis addresses the relationship between innovation and skilled labor shortage in the following way: In a first step, the determinants of labor shortage with a special focus on the role of innovation activities were analyzed. In a second step, the relevance of labor shortage for abandoning innovation activities is investigated. For both steps, endogeneity issues are obvious. While a higher level 
of innovation activities might lead to labor shortage, (expected) labor shortage might also negatively affect innovation activities. Abandoning innovation activities may also affect labor demand if the cancelation of innovation projects is followed by downsizing the projects before, potentially reducing labor demand.

We used an instrumental variable approach to address these endogeneity problems. The estimation results show that innovative firms and thus the driving force of the German economic development are particularly affected by labor shortage. Skilled labor shortage seems to be causal for the cancelation of innovation projects. Interestingly, the lack of vocational skills seems to be even more important for the cancelation of innovation projects compared to academic skills. The current technological change (digitalization, technologies combatting societal challenges) tends to require a combination of different (scarce) skills so that a mere focus on academic skills is not sufficient. The hampering of innovation by skilled labor shortage is thus important for the political agenda as it will reduce productivity increases and growth in wealth of the German economy. From a political side of view, more efforts are inter alia needed concerning the level of vocational training in manufacturing or IT professions. Besides academic qualifications, this "medium" qualification level seems to be also very important for innovation processes. The mere enlargement of the number of students at universities is perhaps not the best way, a better mix between academic and vocational qualifications would be useful. Therefore, a higher social recognition and economic incentives for vocational qualification careers would be necessary.

\section{References}

Acemoglu, D. (2010): When does labor scarcity encourage innovation? Journal of Political Economy 118 (6): 1037-1078.

Arrow, K. J., Capron, W. M. (1959): Dynamic shortages and price rises: the engineer-scientist case. Quarterly Journal of Economics 73 (2): 292-308.

Baird, M., Daugherty, L., Kumar, K. (2019): Improving Estimation of Labor Market Disequilibrium Using Shortage Indicators, with an Application to the Market for Anesthesiologists. IZA Discussion Paper No. 12129, Bonn.

Barbieri, L., Mussida, C., Piva, M., Vivarelli, M. (2019): Testing the Employment and Skill Impact of New Technologies: A Survey and some Methodological Issues. UNU-MERIT Working Paper Series 2019-032, Maastricht. 
Barnow, B. S., Trutko, J., Piatak, J. S. (2013): How do we know occupational labor shortages exist? Employment Research 20 (2): 4-6.

Behrens, V., Berger, M., Hud, M., Hünermund, P., Iferd, Y., Peters, B., Rammer, C., Schubert, T. (2017): Innovation Activities of Firms in Germany - Results of the German CIS 2012 and 2014. ZEW Documentation No. 17-04, Mannheim.

Bennett, J., McGuinness, S. (2009): Assessing the impact of skill shortages on the productivity performance of high-tech firms in Northern Ireland. Applied Economics 41 (6): 727-737.

Berlingieri, F., Erdsiek, D. (2012): How Relevant is Job Mismatch for German Graduates? ZEW Discussion Paper No. 12-075, Mannheim.

Brücker, H., Brunow, S., Fuchs, J., Kubis, A., Mendolicchio, C., Weber, E. (2013): Fachkräftebedarf in Deutschland - Zur kurz- und langfristigen Entwicklung von Fachkräfteangebot und -nachfrage, Arbeitslosigkeit und Zuwanderung. IAB-Stellungnahme 1/2013, Nuremberg.

Cappelli, P. (2015): Skill gaps, skill shortages and skill mismatches: evidence and arguments for the US. Industrial and Labor Relations Review 68 (2): 251-290.

Cedefop (2015): Skill Shortages and Gaps in European Enterprises. Striking a Balance between Vocational Education and Training and the Labour Market. Cedefop Reference Series 102. Luxembourg: Publications Office of the European Union.

Coad, A., Pellegrino, G., Savona, M. (2016): Barriers to innovation and firm productivity. Economics of Innovation and New Technology 25 (3): 321-334.

Cui, Y., Meng, J., Lu, C. (2018): Recent developments in china's labor market: labor shortage, rising wages and their implications. Review of Development Economics 22 (3): 1217-1238.

Czarnitzki, D., Kraft, K., Thorwarth, S. (2009): The knowledge production of 'R' and 'D'. Economic Letters 105 (1): 141-413.

Eurostat (2020): Unemployment Rate - Annual Data, Luxembourg, https://ec.europa.eu/eurostat/databrowser/view/tipsun20/default/table?lang=de.

Freel, M. S. (2005): Patterns of innovation and skills in small firms. Technovation 25 (2): 123134.

Fuchs, J., Söhnlein, D. (2013): Projektion der Erwerbsbevölkerung bis zum Jahr 2060. IABForschungsbericht 10/2013, Nuremberg.

Green, F., Machin, S., Wilkinson, D. (1998): The meaning and determinants of skill shortages. Oxford Bulletin of Economics and Statistics 60 (2): 165-187.

Haskel, J., Martin, C. (2006): Skill shortages, productivity growth and wage inflation. In: Booth, A. L., Snower, D. J. (eds.): Acquiring Skills, Market Failures, their Symptoms and Policy Responses. Cambridge: Cambridge University Press, 147-174. 
Healy, J., Mavromaras, K., Sloane, P. (2015): Adjusting to skill shortages in Australian SMEs. Applied Economics 47 (24): 2470-2487.

Horbach, J. (2014): Determinants of Labor Shortage - with particular Focus on the German Environmental Sector. IAB-Discussion Paper 22/2014, Nuremberg.

Junankar, P. N. (2009): Was there a Skills Shortage in Australia? IZA Discussion Paper No. 4651, Bonn.

Kettner, A. (2012): Fachkräftemangel und Fachkräfteengpässe in Deutschland: Befunde, Ursachen und Handlungsbedarf. Dissertation, Technical University Berlin.

Klingebiel, R., Rammer, C. (2014): Resource allocation strategy for innovation portfolio management. Strategic Management Journal 35 (2): 246-268.

McGuinness, S., Pouliakas, K., Redmond, P. (2017): How Useful Is the Concept of Skills Mismatch? IZA Discussion Paper No. 10786, Bonn.

Müller, A., Rebien, M., Vogler-Ludwig, K. (2012): IAB-Erhebung des Gesamtwirtschaftlichen Stellenangebots - Betriebsbefragung zu Stellenangebot und Besetzungsprozessen. Wellen 2005 bis 2009 und Folgequartale. FDZ Datenreport 02/2012. Nuremberg: Institute for Employment Research.

OECD (2003): Employment Outlook. Paris: OECD Publishing.

Peters, B., Rammer, C. (2013): Innovation panel surveys in Germany. In: Gault, F. (ed.): Handbook of Innovation Indicators and Measurement. Cheltenham: Edward Elgar, 135-177.

Piva, M., Vivarelli, M. (2009): The role of skills as a major driver of corporate R\&D. International Journal of Manpower 30 (8): 835-852.

Röttger, C., Weber, B., Weber, E. (2019): Qualifikationsspezifische Arbeitslosenquoten. Aktuelle Daten und Indikatoren. Nuremberg: Institute for Employment Research.

Shah, C., Burke, G. (2003): Skill Shortages: Concepts, Measurement and Implications. Monash University, Centre for the Economics of Education and Training, Working Paper No. 52, Clayton.

Slavtchev, V., Fritsch, M. (2005): The Role of Regional Knowledge Sources for Innovation: An Empirical Assessment. Freiberger Arbeitspapiere, No. 2005/15, Fakultät für Wirtschaftswissenschaften, Technical University Bergakademie Freiberg.

Song, J., Almeida, P., Wu, G. (2003): Learning-by-hiring: when is mobility more likely to facilitate interfirm knowledge transfer? Management Science 49: 351-65.

Statistisches Bundesamt (2019): Die Regionaldatenbank Deutschland. Wiesbaden: German Statistical Office, https://www.regionalstatistik.de/genesis/online/. 
Svetlik, I., Stavrou-Costea, E. (2007): Connecting human resources management and knowledge management. International Journal of Manpower 28: 197-206.

Tang, J., Wang, W. (2005): Product market competition, skill shortages and productivity: evidence from Canadian manufacturing firms. Journal of Productivity Analysis 23 (3): 317-339.

Toner, P. (2011): Workforce Skills and Innovation: An Overview of Major Themes in the Literature. STI Working Papers Series, OECD.

Wagner, J. (2006): International Firm Activities and Innovation: Evidence from Knowledge Production Functions for German Firms. Working Paper Series in Economics No. 25, University of Lüneburg. 
Table A1: Definition of variables and descriptive statistics

\begin{tabular}{|c|c|c|c|}
\hline Variable & Definition & Mean & SD \\
\hline \multicolumn{4}{|l|}{ Dependent variables } \\
\hline Laborshortbroad & $\begin{array}{l}\text { 1: Vacancies could not be filled at all, only with delay, or not } \\
\text { with the desired personnel in } 2017,0 \text { : Other }\end{array}$ & 0.38 & 0.49 \\
\hline Laborshortnarrow & 1: Vacancies could not be filled at all in 2017, 0 : Other & 0.18 & 0.39 \\
\hline Innovationfail2017 & 1: Cancelation of innovation projects 2015-2017, 0: Other & 0.08 & 0.27 \\
\hline Innovationfail2018 & 1: Cancelation of innovation projects 2016-2018, 0: Other & 0.08 & 0.27 \\
\hline Qualcount & $\begin{array}{l}\text { Number of different required qualifications for vacancies } \\
2017\end{array}$ & 0.80 & 1.32 \\
\hline \multicolumn{4}{|l|}{ Innovative capacity } \\
\hline Shareacad & Share of employees with university degree in 2016 & 0.24 & 0.29 \\
\hline Innovation & $\begin{array}{l}\text { 1: Introduced product or process innovation 2015-2017, 0: } \\
\text { otherwise }\end{array}$ & 0.38 & 0.49 \\
\hline Innobreadth & Number of different innovation activities 2015-2017 & 2.07 & 2.83 \\
\hline \multicolumn{4}{|c|}{ Additional labor shortage indicators } \\
\hline AcademicLS & 1: Labor shortage in academic qualifications 2017, 0: Other & 0.17 & 0.38 \\
\hline VocationalLS & 1: Labor shortage in vocational educations 2017, 0: Other & 0.27 & 0.45 \\
\hline SkilledLS & 1: LS in academic/vocational qualifications 2017, 0: Other & 0.32 & 0.47 \\
\hline UnskilledLS & 1: Labor shortage in unskilled occupations 2017, 0: Other & 0.20 & 0.40 \\
\hline Pathdep & 1: Lack of suitable qualified staff from 2014-2016, 0: Other & 0.35 & 0.48 \\
\hline \multicolumn{4}{|c|}{ Regional variables (NUTS 3) } \\
\hline Dedomainpc & Number of De-domains per 100 inhabitants 2016 & 17.5 & 9.5 \\
\hline GDPemp & GDP per employee (in 1,000) 2016 & 68.2 & 12.3 \\
\hline Popdensity & Inhabitants per square kilometers (in 1,000) 2016 & 1.04 & 1.30 \\
\hline Unemprate & Unemployment rate 2016 & 0.06 & 0.03 \\
\hline \multicolumn{4}{|l|}{ Control variables } \\
\hline Agefirm & Age of the firm (2017 - year of foundation +0.5$) / 10$ & 3.4 & 3.6 \\
\hline Compabroad & 1: Strong competition by foreign firms 2016; 0: Other & 0.30 & 0.46 \\
\hline Compabroad18 & 1: Strong competition by foreign firms 2018; 0: Other & 0.32 & 0.47 \\
\hline Demand & Turnover growth from 2016 to 2017 & 0.03 & 0.23 \\
\hline Empdynamic & Annual growth rate of employment 2010-2017 & 0.02 & 0.07 \\
\hline East Germany & 1: Firm located in Eastern Germany, 0: Other & 0.40 & 0.49 \\
\hline Credrating & Index from -6 (low) to -1 (highest), referring to 2016 & -2.3 & 0.43 \\
\hline Newcomp & 1: Threat to market positions (new entrants) 2016, 0: Other & 0.46 & 0.50 \\
\hline Pricecomp & 1: Price changes induce a loss of customers 2016, 0 : Other & 0.45 & 0.50 \\
\hline Shortlifecycle & 1: Product or services are rapidly obsolete 2016,0 : Other & 0.20 & 0.40 \\
\hline Substitutability & 1: High substitutability by products of comp. 2016, 0 : Other & 0.56 & 0.50 \\
\hline Substitutability18 & 1: High substitutability by products of comp. 2018, 0 : Other & 0.56 & 0.50 \\
\hline Size & Number of employees 2016 (in 1,000) & 0.26 & 3.75 \\
\hline Size17 & Number of employees 2017 (in 1,000) & 0.39 & 8.11 \\
\hline \multicolumn{4}{|l|}{ Sector dummies } \\
\hline Sec1 & Food products and beverages, tobacco & 0.04 & 0.20 \\
\hline Sec2 & Textiles, clothing, leather products & 0.03 & 0.16 \\
\hline Sec3 & Wood and paper products, printing & 0.03 & 0.16 \\
\hline Sec4 & Chemical and pharmaceutical industry & 0.03 & 0.16 \\
\hline Sec5 & Rubber and plastic products & 0.03 & 0.16 \\
\hline Sec6 & Glass, ceramics and concrete products & 0.02 & 0.14 \\
\hline Sec7 & Basic metals and fabricated metals & 0.07 & 0.26 \\
\hline Sec8 & Electrical machinery, electronics, instruments & 0.04 & 0.20 \\
\hline Sec9 & Machinery & 0.06 & 0.24 \\
\hline Sec10 & Motor vehicles, other transport equipment & 0.02 & 0.13 \\
\hline Sec11 & Medial products, furniture and other products & 0.06 & 0.25 \\
\hline Sec12 & Energy and water supply, mining, mineral industry & 0.03 & 0.17 \\
\hline
\end{tabular}




\begin{tabular}{|l|l|c|c|}
\hline Sec13 & Recycling, waste and waste water removal & 0.05 & 0.21 \\
\hline Sec14 & Wholesale trade & 0.04 & 0.19 \\
\hline Sec15 & Transport and logistics & 0.08 & 0.27 \\
\hline Sec16 & Media services & 0.04 & 0.20 \\
\hline Sec17 & Computer programming, data processing, telecommunication & 0.03 & 0.18 \\
\hline Sec18 & 0.05 & 0.21 \\
\hline Sec19 & Financial services & 0.08 & 0.27 \\
\hline Sec20 & Technical and R\&D services & 0.07 & 0.25 \\
\hline Sec21 & Business consulting and advertising & 0.12 & 0.33 \\
\hline
\end{tabular}

Source: German Community Innovation Survey (CIS) 2017, 2018, 2019, own estimations.

\section{Question on labor shortage in the 2017 survey}

\section{Skill Demand}

8.1 To what extent could your enterprise fill job openings during 2017 ? (Multiple responses allowed!) Job openings
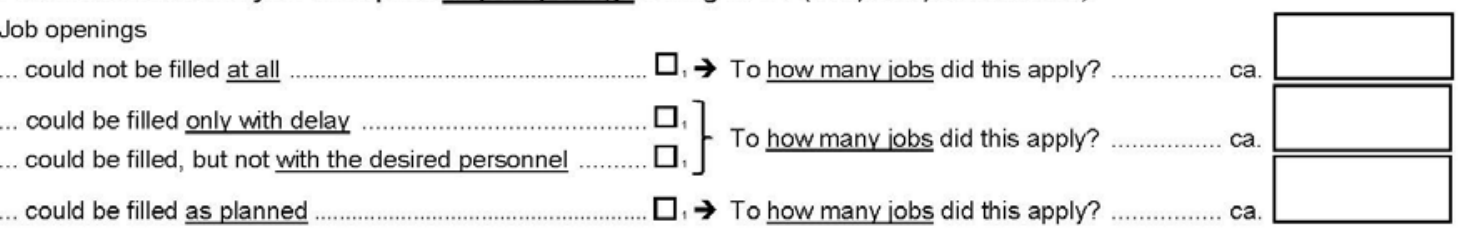

No job offerings during 2017

$\square, \rightarrow$ Please continue with Question 8.3!

8.2 Which level of qualification was required for the open positions in 2017? (Multiple responses allowed!)

Academic qualification

Computer sciences, maths, statistics

Other science and engineering

Others (e.g. business, law)
Vocational education

Manufacturing professions

IT professions

Others
Semiskilled/unskilled tasks

Production

Logistics/transportation

Services
ㅁ.

ㅁ. 
Download ZEW Discussion Papers from our ftp server:

http://ftp.zew.de/pub/zew-docs/dp/

or see:

https://www.ssrn.com/link/ZEW-Ctr-Euro-Econ-Research.html

https://ideas.repec.org/s/zbw/zewdip.html

$$
\text { // }
$$

IMPRINT

ZEW - Leibniz-Zentrum für Europäische Wirtschaftsforschung GmbH Mannheim

ZEW - Leibniz Centre for European

Economic Research

L 7,1 68161 Mannheim · Germany

Phone +49621 1235-01

info@zew.de·zew.de

Discussion Papers are intended to make results of ZEW research promptly available to other economists in order to encourage discussion and suggestions for revisions. The authors are solely responsible for the contents which do not necessarily represent the opinion of the ZEW. 